\section{Human albumin use at hospitals in the Metropolitan Region of Rio de Janeiro, Brazil}

\author{
Uso de albumina humana nos hospitais da Região \\ Metropolitana do Estado do Rio de Janeiro, Brasil
}

\author{
${ }^{1}$ Faculdade de Farmácia, \\ Universidade Federal do Rio \\ de Janeiro, Rio de Janeiro, \\ Brasil. \\ 2 Escola Nacional de Saúde \\ Pública Sergio Arouca, \\ Fundação Oswaldo Cruz, Rio \\ de Janeiro, Brasil. \\ Correspondence \\ G. C. Matos \\ Departamento de \\ Medicamentos, Faculdade \\ de Farmácia, Universidade \\ Federal do Rio de Janeiro. \\ Rua Prof. Rodolpho Rocco 255 \\ 4 a andar, Rio de Janeiro, $R J$ \\ 21941-913, Brasil. \\ guacira@pharma.ufrj.br
}

\section{A
Th
in
tie
he
th
m
co
per
de
bu
1
bu
m
of} The study analyzes the use of human albumin
in hospitals in Rio de Janeiro, Brazil, using inpatient data from the information system of Brazil's health system between 1999 and 2001. Death was the main outcome as patients died in $32 \%$ of admissions in which human albumin was used as compared with $4 \%$ of all admissions in the same period and region. The Charlson Comorbidity Index was included for risk adjustment. Human albumin was used in 10,111 in-patients more than 1 year old. 87,774 50- $\mathrm{ml}$ bottles of 20\% human albumin were consumed at a cost of US\$1,755. The main diagnoses were neoplasms (29.1\%), diseases lic ownership of the hospital, clinical services (as opposed to surgical services), length of stay and use of intensive care. Death was associated with use of more than four bottles of human albumin (PR: 1.30; 99\%CI: 1.23-1.37), adjusted for severity and speciality. The results are cause for concern as they may be related to poor compliance with guidelines, excess of risk to patients and unnecessary expenses for the public health system.

Serum Albumin; Drug Utilization; Pharmacoepidemiology; Health Services Evaluation
Guacira Corrêa de Matos 1

Suely Rozenfeld 2

Monica Martins 2

\section{Introduction}

Human albumin is a widely used, injectable medication developed in the 1940s. However, its use is in question to this day, in view of less costly therapeutic alternatives, such as the crystalloids and non-protein colloids, and continuing controversy over its indications.

Human albumin is considered a safe product as regards transmission of pathogenic agents. At the manufacturing stage it is subjected to a process of sterilisation by pasteurisation at $60^{\circ} \mathrm{C}$ for 10 hours. However, as it is a blood product obtained from human plasma, there may be a risk of virus and sub-viral particle transmission and studies are currently ongoing to improve the inactivation process by nanofiltration 1,2 .

Its indications relate mostly to correction of acute volume deficit and maintenance of plasma colloid osmotic pressure in patients with hypoalbuminaemia from loss or reduced synthesis. However, in many cases, it is possible and even recommended to replace human albumin with synthetic plasma expanders, which reduce the likelihood of adverse effects and treatment costs. The main synthetic expanders are crystalloid solutions (sodium chloride, Ringer) and non-protein colloids (dextran, polygeline, hydroxyethyl starch) 3,4 .

Human albumin is contraindicated in cases of severe anaemia, heart failure, hypersensitivity, prematurity and dehydration (DRUGDEX 
System. Thomson Healthcare; http:/ / www.micro medex.com, accessed on 15/Aug/2008). Adverse effects, including allergic reactions, occur rarely 5 , although some of them may be severe: coagulation disorders, worsening myocardial depression of patients in shock, pulmonary oedema in major burns, haemolysis, hypervolaemic pulmonary oedema, heart failure, aluminium intoxication in prematures and dialysed patients, and nephrotoxicity. Hypersensitivity reactions may occur, with fever, chills, tremors, nausea, abdominal discomfort, malaise, headache, rubor, urticaria, dyspnoea, tachycardia, hypotension and collapse (DRUGDEX System. Thomson Healthcare; http://www. micromedex.com, accessed on 15/Aug/2008).

A systematic review conducted by the Cochrane Injuries Group Albumin Reviewers found no evidence of benefits from using human albumin in reducing mortality among critical patients with hypovolaemia, burns and hypoalbuminaemia, as compared with using other plasma expanders 6 .

Over the past thirty years, clinical studies and human albumin use studies have been carried out in a number of countries, and treatment protocols have been introduced to improve its therapeutic use. The studies revealed 50 to $70 \%$ inappropriate prescriptions, with substantial effects on costs $3,4,7,8,9,10,11$. However, when protocols are in effect, albumin is prescribed more appropriately for the clinical conditions for which it is indicated 4,12 .

In Brazil, critical examinations of human albumin use are scarce and consumption is high. In 2000, 10 tonnes were consumed, less than $10 \%$ of which corresponded to public and private domestic production (Programa Nacional de Sangue, Agência Nacional de Vigilância Sanitária; http://www.anvisa.gov.br/sangue/p_ hemofilia/p_hemoderivados.htm, accessed on 23/Nov/2005). In 2006, the cost of a $50 \mathrm{ml}$ bottle to the Unified National Health System (SUS) was US\$ 14-US\$ 20. In 2007 and 2008, however, that cost rose to US\$ 48-US\$ 66 (Banco de Preços em Saúde, Ministério da Saúde; http:/ /bpreco.saude. gov.br/bprefd/owa/consulta.inicio, accessed on 06/Feb/2006 and 15/Aug/2008). The national regulatory agency (ANVISA) issued the Resolução de Diretoria Colegiada, RDC no. 115, approving guidelines on human albumin use 13 .

In many countries, major administrative data bases have been used for evaluating health service performance 14 , because they permit access to large volumes of information, with short time lapses between the event and its recording and at no additional cost to the health system 15,16 . The Hospital Information System (SIH) of SUS is a nationwide hospital data base. The SIH contains data on high-cost drugs, among them human albumin, which can serve as a source for pharmacoepidemiological studies.

The purpose of this study is to describe and analyse the characteristics of human albumin use in hospital patients in the Metropolitan Region of Rio de Janeiro, according to records in the SIH/SUS.

\section{Method}

\section{Data source and study population}

The data sources were SUS files for the years 1999, 2000 and 2001, contained on CD-ROMs issued monthly and yearly by the SIH.

The study population included patients over one year old admitted to hospitals in the Metropolitan Region of Rio de Janeiro, who were prescribed human albumin during their hospital stay. The Metropolitan Region of Rio de Janeiro comprises 19 municipalities with a total population of $11,649,931$, representing $75 \%$ of the total state population (Secretaria de Estado de Saúde e Defesa Civil; http://www.saude.rj.gov.br/in formacoeds/bancodad.shtml, accessed on 15/ Aug/2008).

\section{Data extraction and study variables}

From the monthly CD-ROMs, the files on authorised special procedures were extracted; and from these, all inpatient records with at least one field containing the human albumin procedure code (92037) were selected. Information was retained on a maximum of four of any other procedures recorded. From the annual CD-ROMs, information on patients, hospitals and admissions was extracted.

The independent variables for patients are demographic (age, sex, municipality of residence) and clinical (primary diagnosis, secondary diagnosis, severity score). The hospital variables are location (municipality) and hospital ownership. Those for hospital treatment are medical service, Intensive Care Unit (ICU) use, procedures performed, authorised special procedures, days of stay and human albumin units per admission. The dependent variable is death.

Obstetrics was classified as a clinical service, because no mention of surgical procedures was found in the records examined. 


\section{Data analysis}

All variables were dichotomised, except severity score and human albumin units administered, which were considered respectively as an ordinal variable and a continuous variable. The differences among the categories are presented as proportions, means and medians and their significance was tested with the Pearson $\chi^{2}$ test.

Preliminary exploration of the data revealed that $32 \%$ of admissions where human albumin was administered resulted in death, as compared with $4 \%$ for total admissions in the same period and region. Given this discrepancy, it was decided to consider death as an outcome. As human albumin is widely used in severe cases, the Charlson Comorbidity Index (CCI), combining age and severity, was included as a risk adjustment technique.

Patient severity was evaluated on the basis of twenty clinical conditions chosen for their importance to patient prognosis; these were attributed points to reflect relative hazard of death, which then made up a score 17,18 . Age was weighted by a value of 1 per 10 -year period from 50 years of age onwards 14 . The scores for the clinical conditions and their "translations" to the International Classification of Diseases, $10^{\text {th }}$ version (ICD-10) 19 are in Table 1.

The proportion of deaths was examined for a possible association with the quantity of human albumin administered, in terms of two categories: above and below the median number of bottles. The rationale behind this criterion is that no single posology is indicated for the cases as a whole.

Multivariate analysis was performed by logbinomial regression, with all variables included simultaneously. Log-binomial regression is the most appropriate method in cross-sectional studies with common outcomes (> 10\%) where prevalence ratio is the measure of choice 20,21 . The prevalence ratio for death was computed with $95 \%$ confidence interval.

Four models are presented, two of them with variables relating to admissions (units of human albumin, CCI, medical service) and two including patient residence, and hospital ownership and location. In the first two models, as there is no cut-off point set for the ideal quantity of human albumin to be used, the number of bottles was considered as a continuous variable. In the

Table 1

Charlson Comorbidity Index (CCl) - weights of clinical conditions and ICD-10 codes (International Classification of Diseases

10th version).

\begin{tabular}{|c|c|c|}
\hline Weights & Clinical condition & ICD-10 \\
\hline \multirow[t]{10}{*}{1} & Myocardial infarction & $121-125$ \\
\hline & Congestive heart failure & $111,150(0-1-9)$ \\
\hline & Peripheral vascular disease & $171-174$ e 177 \\
\hline & Dementia & F00-F03, G20, G30.9 \\
\hline & Cerebrovascular disease & $160-167$ \\
\hline & Chronic pulmonary disease & J42-J47 \\
\hline & Connective tissue disease & M30-M36 \\
\hline & Diabetes without complications & E10.9, E11.9, E12.9, E13.9, E14.9 \\
\hline & Ulcer & K25-K28 \\
\hline & Mild liver disease & K70-K72, K74-K76 \\
\hline \multirow[t]{6}{*}{2} & Hemiplegia or paraplegia & G81-G83 \\
\hline & Moderate and severe renal disease & I12-I15, N00-N03, N05, N17,N18,N19 \\
\hline & Diabetes with complications & E10-E14 (0-8) \\
\hline & Neoplasms & $\mathrm{C} 00-\mathrm{C} 76$ \\
\hline & Leukaemia & C91-C95 \\
\hline & Lymphoma & C81-C85 \\
\hline 3 & Moderate or severe liver disease & $\mathrm{K} 73, \mathrm{~K} 76.6,185$ \\
\hline \multirow[t]{2}{*}{6} & Malignancy or metastatic tumour * & C97 \\
\hline & AIDS & B20-B24 \\
\hline
\end{tabular}

* Corresponds to two clinical conditions. 
latter two models, the number of bottles was analysed in terms of two categories by the median value.

The software used for data extraction, data base preparation and analysis were Tabwin 3.0 (DATASUS; http://www.datasus.gov.br), SPSS 11.0 (SPSS Inc., Chicago, U.S.A.) and R 2.7.2 (The R Foundation for Statistical Computing, Vienna, Austria; http://www.r-project.org).

The study project was approved by the Research Ethics Committee of the Sergio Arouca School of Public Health, Oswaldo Cruz Foundation (CEP/ENSP/FIOCRUZ - parecer no. 110/02).

\section{Results}

Among inpatients who received human albu$\mathrm{min}$, the most frequent diagnoses are shown in Table 2. In first place are cancers $(29.1 \%)$, followed by diseases of the digestive system (17.5\%) and diseases of the circulatory system (16\%). The most frequent cancers were those of the digestive system (42.5\%). The most frequent diseases of the digestive system were of the liver and the bile ducts $(27 \%)$. The most frequent diseases of the circulatory system were ischaemic heart diseases $(41.5 \%)$. Secondary diagnosis was given only in $27 \%$ of admissions.

From 1999 to 2001 human albumin was used in 10,111 inpatients over 1 year of age, $53.2 \%$ of which were male. The mean age was 52 years and the median, 56 years (Table 3 ). Hospitals located in Rio de Janeiro City accounted for $95 \%$ of admissions, although only $70 \%$ of admissions were patients resident in the municipality. Hospitalisations were $98 \%$ in public hospitals, $42 \%$ in teaching hospitals, $32 \%$ in municipal hospitals and $15 \%$ in state hospitals. Mean and median length of stay were 21 and 15 days, respectively. From these admissions, death rate was $32 \%$ and ICU admissions were $40 \%$.

The data shows consumption of 87,774 units ( $50 \mathrm{ml}$ bottles) of human albumin at $20 \%, 62 \%$ of them in surgical services. Mean consumption was estimated at 8.7 units per admission, with a median of four units.

Table 3 shows the distribution of admissions by patient characteristics, hospitalisations and hospitals, as well as the proportion of deaths in each stratum. A small difference in death rate was found between the sexes (higher for women), but was of no statistical significance $(p=0.07)$. Higher percentages of deaths occurred among patients residing in Rio de Janeiro City, hospitalised for more than 15 days, in clinical wards, in public hospitals, and in hospitals outside Rio de Janeiro City $(\mathrm{p} \leq 0.001)$. As expected, there was a higher percentage of deaths among patients admitted to ICU and among patients who were more severe, older and who received more than four bottles (units) of human albumin ( $\mathrm{p} \leq 0.001$ ).

The results shown in Table 4 suggest that death is associated positively with the amount of human albumin administered, even when the data are stratified for medical service type and for severity. The estimates suggest a quantitative interaction between human albumin use and type of service, with greater hazard of death for patients admitted to surgical cases than to clinical. In addition, there are signs of a qualitative interaction between human albumin use and severity: the hazard of death increases with the amount of human albumin administered only among the severest cases.

In the log-binomial regression (Table 5), in the four models presented, the hazard of death was associated $(\mathrm{p}<0.01)$ positively with greater severity, with medical service type (greater in clinical than in surgical services), with residence in Rio de Janeiro City, with admission to a public hospital and with hospitalisation in a municipality other than Rio de Janeiro (Table 4). No association was observed between the amount of human albumin used and death when the variable "number of bottles" was considered as continuous (model 1 and model 2). However, when the variable was stratified, use of four or more bottles of human albumin increased the hazard of death by $30 \%$ or $27 \%$, in model 3 and in model 4 , respectively.

\section{Discussion}

There were approximately 3,400 hospital admissions a year that involved human albumin prescriptions, most of them for adults and in hospitals located in Rio de Janeiro City. Hospital stays were long, $40 \%$ of patients were admitted to ICU and one third of all admissions resulted in death. The most frequent diagnoses were cancer, and diseases of the digestive and circulatory systems.

Among admissions that resulted in death patients were older and more severe, their hospital stays were longer and consumed more doses of human albumin. The likelihood of death was about two-and-a-half times higher among clinical cases than surgical cases, although the latter were more severe.

A previous study conducted at a public hospital in Rio de Janeiro City estimated that $46 \%$ of total albumin prescriptions and $61 \%$ of inappropriate albumin prescriptions were made among surgical cases 22 . In the present study, the available data gave no basis for evaluating 
Table 2

Characteristics of admissions with use of human albumin, by principal diagnosis, by International Classification of Diseases, 10th version (ICD-10) chapters.

Metropolitan Region of Rio de Janeiro State, Brazil, 1999 to 2001.

\begin{tabular}{|c|c|c|c|}
\hline Principal diagnosis by ICD-10 chapter & Frequency & $\begin{array}{c}\% \text { in } \\
\text { chapter }\end{array}$ & $\%$ in total \\
\hline \multicolumn{4}{|l|}{ II - Neoplasms [code] } \\
\hline Malignant neoplasms of digestive organs [C15-C16-C18-C19-C20-C21-C22-C25] & 1,253 & 42.5 & 12.4 \\
\hline Malignant neoplasms of genital organs [C53-C56-C61-C64-C67] & 483 & 16.4 & 4.8 \\
\hline Malignant neoplasms of lymphoid, haematopoietic and related tissue [C83-C85-C90-C91-C92] & 217 & 7.4 & 2.1 \\
\hline Malignant neoplasms of respiratory organs [C32-C34] & 121 & 4.1 & 1.2 \\
\hline Malignant neoplasms of mesothelial and soft tissue [C48-C49] & 78 & 2.6 & 0.8 \\
\hline Malignant neoplasms of brain [C71] & 73 & 2.5 & 0.7 \\
\hline Malignant neoplasms of breast [C50] & 69 & 2.3 & 0.7 \\
\hline Benign neoplasms of other and ill-defined parts of digestive system [D13] & 30 & 1.0 & 0.3 \\
\hline Malignant neoplasms of unspecified site [C80] & 26 & 0.9 & 0.3 \\
\hline Other malignant neoplasms of skin [C44] & 25 & 0.8 & 0.2 \\
\hline Others & 572 & 19.4 & 5.7 \\
\hline Total & 2,947 & 100.0 & 29.1 \\
\hline \multicolumn{4}{|l|}{$X I$ - Diseases of the digestive system [code] } \\
\hline Diseases of liver [K70-K72-K74] & 477 & 27.0 & 4.7 \\
\hline Diseases of intestines and peritoneum [K56-K59-K63-K65] & 398 & 22.5 & 3.9 \\
\hline Diseases of stomach and duodenum [K25-K31] & 182 & 10.3 & 1.8 \\
\hline Disorders of gallbladder [K80-K81-K82] & 161 & 9.1 & 1.6 \\
\hline Other diseases of digestive system [K92] & 134 & 7.6 & 1.3 \\
\hline Acute pancreatitis [K85] & 53 & 3.0 & 0.5 \\
\hline Others & 364 & 20.6 & 3.6 \\
\hline Total & 1,769 & 100.0 & 17.5 \\
\hline \multicolumn{4}{|l|}{ IX - Diseases of the circulatory system [code] } \\
\hline Ischaemic heart diseases [|20-|21-|24-|25] & 671 & 41.5 & 6.6 \\
\hline Heart failure [150] & 258 & 16.0 & 2.6 \\
\hline Rheumatic valve diseases [105-106] & 163 & 10.1 & 1.6 \\
\hline Cerebrovascular diseases [164-167] & 105 & 6.5 & 1.0 \\
\hline Aortic aneurysm and dissection [171] & 65 & 4.0 & 0.6 \\
\hline Nonrheumatic aortic valve disorders [135] & 31 & 1.9 & 0.3 \\
\hline Others & 323 & 20.0 & 3.2 \\
\hline Total & 1,616 & 100.0 & 16.0 \\
\hline \multicolumn{4}{|l|}{ XIX - Injury, poisoning and certain other consequences of external causes [code] } \\
\hline Burns classified according to extent of body surface involved [T31] & 387 & 45.9 & 3.8 \\
\hline Open wounds involving multiple body regions [T01] & 97 & 11.5 & 1.0 \\
\hline Complications of procedures, not elsewhere classified [T81] & 67 & 7.9 & 0.7 \\
\hline Fractures involving multiple body regions [T02] & 61 & 7.2 & 0.6 \\
\hline Fracture of femur [S72] & 46 & 5.5 & 0.5 \\
\hline Intracranial injury [S06] & 28 & 3.3 & 0.3 \\
\hline Others & 158 & 18.7 & 1.6 \\
\hline Total & 844 & 100.0 & 8.3 \\
\hline \multicolumn{4}{|l|}{ I - Certain infectious and parasitic diseases [code] } \\
\hline Other septicaemia [A41] & 538 & 69.8 & 5.3 \\
\hline HIV disease resulting in infectious and parasitic diseases [B20] & 87 & 11.3 & 0.9 \\
\hline \multicolumn{4}{|l|}{ with or without culture $[\mathrm{A} 15]$} \\
\hline Others & 119 & 15.4 & 1.2 \\
\hline Total & 771 & 100.0 & 7.6 \\
\hline Total of most frequent diagnoses & 7,947 & - & 78.6 \\
\hline Other diagnoses & 2,164 & - & 21.4 \\
\hline Total & 10,111 & - & 100.0 \\
\hline
\end{tabular}


Table 3

Occurrence of death in hospital admissions with use of human albumin, prevalence ratio and confidence intervals. Metropolitan Region of Rio de Janeiro State, Brazil, 1999 to 2001.

\begin{tabular}{|c|c|c|c|c|}
\hline Variables/Categories & $n[N=10,111]$ & Death (\%) [31.7] & $p$ value & PR $(95 \% \mathrm{Cl})$ \\
\hline \multicolumn{5}{|l|}{ Sex } \\
\hline Male & 5,383 & 30.9 & 0.065 & $1.06(1.00-1.12)$ \\
\hline Female & 4,728 & 32.6 & & \\
\hline \multicolumn{5}{|l|}{ Age (median $=56$ years) } \\
\hline$\leq 56$ & 5,084 & 24.7 & $<0.001$ & $1.57(1.48-1.66)$ \\
\hline$>56$ & 5,027 & 38.7 & & \\
\hline \multicolumn{5}{|c|}{ Hospital in Rio de Janeiro municipal area } \\
\hline No & 524 & 51.3 & $<0.001$ & $0.60(0.55-0.65)$ \\
\hline Yes & 9,587 & 30.6 & & \\
\hline \multicolumn{5}{|c|}{ Residence in Rio de Janeiro municipal area } \\
\hline No & 3,042 & 27.2 & $<0.001$ & $1.23(1.15-1.32)$ \\
\hline Yes & 7,069 & 33.6 & & \\
\hline \multicolumn{5}{|l|}{ Ownership of hospital } \\
\hline Private & 249 & 22.1 & 0.001 & $1.45(1.14-1.83)$ \\
\hline Public & 9,862 & 31.9 & & \\
\hline \multicolumn{5}{|l|}{ Medical service type } \\
\hline Surgical & 6,237 & 19.7 & $<0.001$ & $2.59(2.44-2.75)$ \\
\hline Clinical & 3,874 & 51.0 & & \\
\hline \multicolumn{5}{|c|}{ Length of stay (median $=15$ days) } \\
\hline$\leq 15$ & 5,249 & 29.5 & $<0.001$ & $1.16(1.09-1.23)$ \\
\hline$>15$ & 4,862 & 34.1 & & \\
\hline \multicolumn{5}{|l|}{ Intensive Care Units use } \\
\hline No & 6,082 & 28.1 & $<0.001$ & $1.32(1.24-1.40)$ \\
\hline Yes & 4,029 & 37.1 & & \\
\hline \multicolumn{5}{|c|}{ Units of human albumin (median $=4$ bottles) } \\
\hline$\leq 4$ & 5,110 & 25.5 & $<0.001$ & $1.49(1.40-1.58)$ \\
\hline$>4$ & 5,001 & 31.7 & & \\
\hline \multicolumn{5}{|c|}{ Charlson Comorbidity Index (CCl) combined with age } \\
\hline 0 & 2,430 & 23.0 & & \\
\hline 1 & 1,045 & 33.6 & $<0.001$ & $1.46(1.31-1.63)$ \\
\hline 2 & 2,088 & 29.8 & $<0.001$ & $1.29(1.17-1.43)$ \\
\hline 3 & 1,711 & 37.1 & $<0.001$ & $1.61(1.46-1.77)$ \\
\hline 4 & 1,546 & 34.7 & $<0.001$ & $1.51(1.36-1.67)$ \\
\hline$\geq 5$ & 1,291 & 38.8 & $<0.001$ & $1.69(1.53-1.86)$ \\
\hline
\end{tabular}

the proportion of inappropriate prescriptions. However, the hypothesis that the surgical clinics prescribe albumin in greater proportions and on rather weak indication criteria is reinforced by studies in other countries. In a 1994 study at 15 university hospitals in the USA, where albumin was prescribed mainly by surgeons $(45 \%)$ and anaesthetists $(20 \%)$, the authors recommended educational efforts directed to those specialists 9 . In 2000, another study in 53 hospitals in the USA found that albumin was most often prescribed
(54\%) by surgeons. Of that total, cardiac, vascular and thoracic surgeons prescribed $70 \%$ and the proportion of inappropriateness was $55 \% 10$.

The data base used in this study suffers from limitations resulting from its structure. The SIH/ SUS makes provision for recording only one secondary diagnosis, thus restricting the validity of comorbidity-based severity indices. In countries with data bases that allow up to 15 clinical conditions to be recorded, indices can better express severity. In addition, the weightings given to 
Table 4

Proportion of deaths in hospital admissions with use of human albumin, by amount administered, medical service type and severity. Metropolitan Region of Rio de Janeiro State, Brazil, 1999 to 2001.

\begin{tabular}{lccccc}
\hline Categories & $\begin{array}{c}\text { Units of } \\
\text { human albumin } \\
\text { (median }=4 \\
\text { bottles) }\end{array}$ & $n$ [N =10,111] & Death (\%) [31.7] & p value & PR (95\%Cl) \\
& $\leq 4$ & 1,736 & 45.9 & $<0.001$ & $1.20(1.13-1.28)$ \\
\hline Clinical service & $>4$ & 2,138 & 55.1 & & \\
Surgical service & $\leq 4$ & 3,374 & 15.0 & $<0.001$ & $1.68(1.51-1.86)$ \\
CCl combined with age $=0$ & $>4$ & 2,863 & 25.2 & & \\
& $\leq 4$ & 1,231 & 21.5 & 0.08 & $1.14(0.98-1.32)$ \\
$\mathrm{CCl}$ combined with age $\geq 1$ & $>4$ & 1,199 & 24.5 & & \\
\hline
\end{tabular}

Table 5

Occurrence of death in admissions involving use of human albumin, on four models, prevalence ratio (PR) and $99 \%$ confidence intervals $(99 \% \mathrm{Cl})$. Metropolitan Region of Rio de Janeiro State, Brazil, 1999 to 2001.

\begin{tabular}{|c|c|c|c|c|}
\hline \multirow[t]{2}{*}{ Variables } & \multicolumn{2}{|c|}{ Model 1} & \multicolumn{2}{|c|}{ Model 2} \\
\hline & PR & $99 \% \mathrm{Cl}$ & PR & $99 \% \mathrm{Cl}$ \\
\hline Units of human albumin (bottles) & 1.00 & $1.00-1.01$ & 1.00 & $1.00-1.01$ \\
\hline \multicolumn{5}{|c|}{ Charlson Comorbidity Index (CCl) combined with age } \\
\hline 0 & 1.00 & & 1.00 & \\
\hline 1 & 1.47 & $1.37-1.56$ & 1.55 & $1.41-1.70$ \\
\hline 2 & 1.54 & $1.44-1.64$ & 1.31 & $1.19-1.44$ \\
\hline 3 & 1.75 & $1.64-1.86$ & 1.58 & $1.45-1.73$ \\
\hline 4 & 1.54 & $1.42-1.68$ & 1.53 & $1.40-1.68$ \\
\hline$\geq 5$ & 1.82 & $1.70-1.94$ & 1.32 & $1.22-1.43$ \\
\hline \multicolumn{5}{|l|}{ Medical service type } \\
\hline Surgical & 1.00 & & 1.00 & \\
\hline Clinical & 2.83 & $2.70-2.97$ & 2.44 & $2.30-2.58$ \\
\hline \multicolumn{5}{|c|}{ Residence in Rio de Janeiro municipal area } \\
\hline No & & & 1.00 & \\
\hline Yes & & & 1.22 & $1.14-1.30$ \\
\hline \multicolumn{5}{|l|}{ Ownership } \\
\hline Private & & & 1.00 & \\
\hline Public & & & 1.48 & $1.18-1.85$ \\
\hline \multicolumn{5}{|c|}{ Hospital in Rio de Janeiro municipal area } \\
\hline No & & & 1.00 & \\
\hline \multirow[t]{3}{*}{ Yes } & & & 0.66 & $0.60-0.72$ \\
\hline & \multicolumn{2}{|c|}{ Model 3} & \multicolumn{2}{|c|}{ Model 4} \\
\hline & PR & $99 \% \mathrm{Cl}$ & PR & $99 \% \mathrm{Cl}$ \\
\hline \multicolumn{5}{|l|}{ Units of human albumin (bottles) } \\
\hline$\leq 4$ & 1.00 & & 1.00 & \\
\hline$>4$ & 1.30 & $1.23-1.37$ & 1.27 & $1.21-1.34$ \\
\hline
\end{tabular}

(continues) 
Table 5 (continued)

\begin{tabular}{|c|c|c|c|c|}
\hline \multirow[t]{2}{*}{ Variables } & \multicolumn{2}{|c|}{ Model 3} & \multicolumn{2}{|c|}{ Model 4} \\
\hline & PR & $99 \% \mathrm{Cl}$ & PR & $99 \% \mathrm{Cl}$ \\
\hline \multicolumn{5}{|c|}{ Charlson Comorbidity Index (CCl) combined with age } \\
\hline 0 & 1.00 & & 1.00 & \\
\hline 1 & 1.29 & $1.16-1.44$ & 1.29 & $1.16-1.43$ \\
\hline 2 & 1.28 & $1.17-1.41$ & 1.30 & $1.18-1.42$ \\
\hline 3 & 1.59 & $1.46-1.74$ & 1.66 & $1.50-1.84$ \\
\hline 4 & 1.54 & $1.41-1.69$ & 1.58 & $1.46-1.71$ \\
\hline$\geq 5$ & 1.64 & $1.50-1.80$ & 1.61 & $1.47-1.77$ \\
\hline \multicolumn{5}{|c|}{ Medical service type } \\
\hline Surgical & 1.00 & & 1.00 & \\
\hline Clinical & 2.50 & $2.36-2.65$ & 2.43 & $2.29-2.57$ \\
\hline \multicolumn{5}{|c|}{ Residence in Rio de Janeiro municipal area } \\
\hline No & & & 1.00 & \\
\hline Yes & & & 1.24 & $1.18-1.32$ \\
\hline \multicolumn{5}{|l|}{ Ownership } \\
\hline Private & & & 1.00 & \\
\hline Public & & & 1.35 & $1.09-1.68$ \\
\hline \multicolumn{5}{|c|}{ Hospital in Rio de Janeiro municipal area } \\
\hline No & & & 1.00 & \\
\hline Yes & & & 0.68 & $0.63-0.74$ \\
\hline
\end{tabular}

clinical conditions and age were those proposed for the US population and may therefore be inappropriate for our population. In this study, we worked with the weightings proposed by the authors of the original study, which have been used in international studies 17. Risk adjustment was probably incomplete because the CCI does not contemplate clinical conditions that are important in paediatrics.

In addition to describing aspects of admissions involving prescription of human albumin, this study sought to examine a possible interpretation for the deaths. It was observed that the use of more than four units (bottles) of human albumin increased the likelihood of death by $30 \%$, even when adjusted for severity and medical service type.

The associations encountered in models 2 and 4 with patient residence, hospital ownership and hospital location may be biased by other factors, such as differences among groups in terms of access to health services and treatments.

For the purposes of health service research, epidemiological studies and health surveillance, the SIH/SUS is an important source of information on hospital service programming, management and evaluation 16,23. The SUS information processing department (DATASUS) has helped improve data base quality. However, the database input routine records information by admis- sion and not by patient. This leads to persistent problems as regards morbidity, data validity and failure to identify re-admissions and transfers, which may lead to double counting of patients. In addition, the scarcity of patient clinical data is a considerable disadvantage, because it restricts the number of risk variables available for adjusting performance measures 14,16.

To date, little advantage has been taken of the SIH/SUS for pharmacoepidemiological analyses, and this study shows that it can contribute to an understanding of the use of high-cost drugs, such as human albumin. However, information is available on only 48 drugs and these are largely high-cost drugs such as blood products and immunosuppressants for a restricted set of diseases. There is no information on other drugs prescribed during the hospital stay. Research into drug use patterns in hospitals by way of a nationwide data base is limited to these drugs. In addition, recovery of information on drugs entails lengthy data processing, numerous month-bymonth file correlations, and data extraction.

The number of prescriptions is probably underestimated as a result of under-recording of albumin use in the SIH/SUS. A previous study in a federal public hospital found that 7,980 $50 \mathrm{~mL}$ bottles of $20 \%$ albumin were consumed in 200122 . In the same year, however, the SIH/SUS records consumption of only 285 bottles. That 
finding may possibly indicate that the procedure is recorded only for the purpose of reimbursing hospital costs and that, in facilities which manage their own finances, under-recording is very high. In the same way, the Rio de Janeiro State health department (SES/RJ) recorded distribution of 11,118 bottles of albumin to state hospitals in 2001. However, SIH/SUS records for the same year show only 699 bottles, which in addition to indicating major under-recording of consumption, prevents SES/RJ from monitoring prescription effectiveness and appropriateness.

If the cost of albumin is estimated at US\$ 2 per gram, total spending on this product in the present study would be US\$1,755, and mean expenditure per admission, US\$174. Applying the $62 \%$ inappropriate prescription estimated in the prior study 22 yields estimated unnecessary expenditure of US $\$ 1,088,000$, which is a cause for concern. Although the comparison should be viewed with caution given that the study in question was conducted in a single hospital, it does point to a need to ascertain the situation in Brazil nationally and then to expand application of the ANVISA protocol and improve indication of human albumin. The economic impact of inappropriate use is even greater if one considers the prices currently paid by the SUS. Ministry of Health figures show a $300 \%$ increase in the price of human albumin in 2007 as compared with 2006.

This study intended to explore the use of a national administrative data base in a Latin American country which, combined with data extracted from medical records and hospital pharmacy records, would make it possible to improve the quality of drug use. In addition, the application of treatment protocols would allow for improvements in the quality of medical care.

\section{Resumo}

O estudo analisou o uso da albumina humana em hospitais do Rio de Janeiro, Brasil, utilizando os registros do Sistema de Informações Hospitalares do Sistema Único de Saúde (SIH/SUS), 1999 e 2001. Como 32\% das internações resultaram em óbito, em comparação com $4 \%$ de óbito para todas as internações no mesmo período e região, este foi o desfecho principal do estudo. A albumina humana foi usada em 10.111 internações de maiores de um ano, que consumiram 87.774 frascos - 50mL a 20\%, com gasto de US\$1.755,00. Os principais diagnósticos foram neoplasias $(29,1 \%)$, doenças do aparelho digestivo (17,5\%) e do aparelho circulatório (16\%). Houve maior proporção de óbitos de pacientes mais idosos, que receberam mais doses de albumina humana, internados por mais tempo, em especialidades clínicas, em UTI, em hospitais públicos. O óbito esteve associado ao uso de mais de quatro frascos de albumina humana (RP: 1,30; IC99\%: 1,23-1,37), ajustado por gravidade e especialidade. Os resultados evidenciam a baixa adesão aos protocolos, o excesso de risco para os pacientes e os gastos desnecessários para o sistema público de saúde.

Albumina Sérica; Uso de Medicamentos; Farmacoepidemiologia; Avaliação de Serviços de Saúde

\section{Contributors}

G. C. Matos participated in the design, planning, data collection, analysis, data interpretation, and drafting of the paper. S. Rozenfeld conceived the study and the design, participated in planning, analysis, data interpretation, critical review of the content, and approval of the paper's final version. M. Martins participated in the design, planning, data collection, analysis, data interpretation, critical review of the content.

\section{Acknowledgments}

Special thanks to Dr. Cosme M. F. Passos da Silva for collaborating with the statistical data analysis. 


\section{References}

1. Lesne-Hulin A, Bourget PH, Silvie M, Barath V, Singlas E. Traçabilité des médicaments dérivés du sang: réglementation et implications pharmacoéconomiques après 24 mois d'exercice dans un CHU parisien. Pathol Biol (Paris) 1997; 45:741-50.

2. Sweetman SC. Martindale: the complete drug reference $[\mathrm{CD}-\mathrm{ROM}]$. London: Pharmaceutical Press; 2004.

3. Vermeulen Jr. LC, Ratko TA, Erstad BL, Brecher ME, Matuszewski KA. A paradigm for consensus. The University Hospital Consortium guidelines for the use of albumin, nonprotein colloid, and crystalloid solutions. Arch Intern Med 1995; 155:373-9.

4. Tarín-Remohi MJ, Sánchez-Arcos A, Santos-Ramos B, Bautista-Paloma J, Guerrero-Aznar MD. Costs related to inappropriate use of albumin in Spain. Ann Pharmacother 2000; 34:1198-205.

5. Gonzalez ER, Kannwurf B. The clinical use of albumin. US Pharm 1998; 23:HS15-26.

6. The Albumin Reviewers. Human albumin solution for resuscitation and volume expansion in critically ill patients. Cochrane Database of Systematic Reviews. Issue 4; 2004. http://www.mrw. interscience.wiley.com/cochrane (accessed on 15/ Aug/2008)

7. Tullis JL. Albumin. 1. Background and use. JAMA 1977; 237:355-60.

8. Tullis JL. Albumin. 2. Guidelines for clinical use. JAMA 1977; 237:460-3.

9. Yim JM, Vermeulen LC, Erstad BL, Matuszewski KA, Burnett DA, Vlasses PH. Albumin and nonprotein colloid solution use in US academic health centers. Arch Intern Med 1995; 155:2450-5.

10. Tanzi M, Gardner M, Megellas M, Lucio S, Restino M. Evaluation of the appropriate use of albumin in adult and pediatric patients. Am J Health Syst Pharm 2003; 60:1330-5.

11. Vargas E, de Miguel V, Portolés A, Avendaño C, Ambit MI, Torralba A, et al. Use of albumin in two Spanish university hospitals. Eur J Clin Pharmacol 1997; 52:465-70.

12. Debrix I, Combeau D, Stephan F, Benomar A, Becker A. Clinical practice guidelines for the use of albumin: results of a drug use evaluation in a Paris hospital. Pharm World Sci 1999; 21:11-6.
13. Agência Nacional de Vigilância Sanitária/Ministério da Saúde. Resolução de Diretoria Colegiada no 115. Aprova as diretrizes para o uso de albumina humana. Diário Oficial da União 2004; 11 mai.

14. Martins M, Travassos C, Noronha JC. Sistema de Informações Hospitalares como ajuste de risco em índices de desempenho. Rev Saúde Pública 2001; 35:185-92.

15. Bittencourt AS, Camacho LAB, Leal MC. O Sistema de Informação Hospitalar e sua aplicação na saúde coletiva. Cad Saúde Pública 2006; 22:19-30.

16. Lessa FJD, Mendes ACG, Farias S, Fet AL. Novas metodologias para vigilância epidemiológica: uso do Sistema de Informações Hospitalares - SIH/ SUS. Inf Epidemiol SUS 2000; 9:3-27.

17. Charlson ME, Szatrowski TP, Peterson J, Gold J. Validation of a combined comorbidity index. J Clin Epidemiol 1994; 47:1245-51.

18. D'Hoore W, Boukaert A, Tilquin C. Practical considerations on the use of the Charlson Comorbidity Index with administrative data bases. J Clin Epidemiol 1996; 49:1429-33

19. World Health Organization. ICD-10 - International Statistical Classification of Diseases and Related Health Problems - Tenth Revision. http://www. who.int/classifications/apps/icd/icd10online (accessed on 15/Aug/2008).

20. Barros AJD, Hirakata VN. Alternatives for logistic regression in cross-sectional studies: an empirical comparison of models that directly estimate the prevalence ratio. BMC Med Res Methodol 2003; 3:21.

21. Greenland S. Model-based estimation of relative risks and other epidemiologic measures in studies of common outcomes and in case-control studies. Am J Epidemiol 2004; 160:301-5.

22. Matos GC, Rozenfeld S. Avaliação do uso de albumina humana em hospital do Rio de Janeiro, Brasil. Cad Saúde Pública 2005; 21:1224-33.

23. Veras CMT, Martins MS. A confiabilidade dos dados nos formulários de Autorização de Internação Hospitalar (AIH), Rio de Janeiro, Brasil. Cad Saúde Pública 1994; 10:339-55.

Submitted on 29/Jul/2009

Final version resubmitted on $03 / \mathrm{Feb} / 2010$

Approved on 01/Mar/2010 